\title{
Dendryphion penicillatum and Pleospora papaveracea, Destructive Seedborne Pathogens and Potential Mycoherbicides for Papaver somniferum
}

\author{
Nichole R. O'Neill, James C. Jennings, Bryan A. Bailey, and David F. Farr
}

First author: Soybean and Alfalfa Research Laboratory; second author: Weed Science Laboratory; third author: Biocontrol of Plant Diseases Laboratory; and fourth author: Systematic Mycology and Botany Laboratory, USDA, ARS, Beltsville, MD 20705.

Accepted for publication 25 February 2000.

\begin{abstract}
O'Neill, N. R., Jennings, J. C., Bailey, B. A, and Farr, D. F. 2000. Dendryphion penicillatum and Pleospora papaveracea, destructive seedborne pathogens and potential mycoherbicides for Papaver somniferum. Phytopathology 90:691-698.

Dendryphion penicillatum and Pleospora papaveracea were isolated from blighted Papaver somniferum and Papaver bracteatum plants grown in growth chambers and the field in Beltsville, MD. The etiology of the diseases was determined, and the fungi are being investigated as potential mycoherbicides to control the narcotic opium poppy plant. $P$. papaveracea is known to be a highly destructive seedborne pathogen of Papaver somniferum, causing seedling blight, leaf blight, crown rot, and capsule rot. Single conidia and ascospores were isolated and cultures established from naturally infested seed and diseased foliage and pods of opium poppy from Iran, Colombia, Venezuela, Sweden, India, and the United States (Maryland and Washington). Mycelia and conidia of P. papaveracea and $D$. penicillatum produced on necrotic leaf tissues appear morphologically similar, and the fungi were previously considered to be anamorph and teleomorph. However, no anamorph/teleomorph connection could be

established, and the fungi appear to be distinct taxa. P. papaveracea produced conidia, mature pseudothecia, and chlamydospores in vitro and on infected stems. D. penicillatum produced conidia, microsclerotia, and macronematous conidiophores. Although both fungi were pathogenic to three poppy cultivars, conidial inoculum from $P$. papaveracea cultures was more virulent than conidial inoculum from $D$. penicillatum. Eightweek-old plants became necrotic and died 8 days after inoculation with a conidial suspension of $P$. papaveracea at $2 \times 10^{5}$ spores per ml. Disease severity was significantly enhanced by inoculum formulations that contained corn oil, by higher conidial inoculum concentrations, and by increased wetness periods. Symptoms on plants inoculated with either pathogen included leaf and stem necrosis, stem girdling, stunting, necrotic leaf spots, and foliar and pod blight. Inoculated seedlings exhibited wire stem, damping-off, and root rot. Conidia, and less frequently pseudothecia, of $P$. papaveracea and conidia of $D$. penicillatum were produced abundantly on inoculated, necrotic foliage, pods, and seedlings. Cultures from conidia or ascospores reisolated from these tissues consistently produced fungi whose morphologies were typical of the fungus from which the inoculum was derived.
\end{abstract}

In 1996, opium poppy (Papaver somniferum L.) seedlings and mature plants produced from Plant Introduction (PI) seed accessions grown in greenhouses and growth chambers in Beltsville, MD, were dying of an unknown disease that spread rapidly throughout the collection, killing the majority of over 200 accessions. Symptoms included seedling wire stem, foliage and stem necrosis, and blight of mature plants. Conidia were produced abundantly on seed, diseased leaves, and symptomatic plants from the field. Microsclerotia were observed in water-soaked roots of seedlings, on seed coats, and in infected and water-soaked mature plant tissues. A few accessions grown in the field exhibited foliar leaf spot and necrotic spots on pods.

Dendryphion penicillatum (Corda) Fr. (synanamorph Helminthosporium papaveris $\mathrm{K}$. Sawada) is a seedborne pathogen that is known to cause a highly destructive disease of opium poppy in countries in Europe and Asia where Papaver somniferum is grown $(9,13,23)$. The teleomorph of the fungus has been considered to be Pleospora papaveracea (de Not.) Sacc. Work on the disease has been described from several European countries, as well as the United States, India, and Japan $(5,7,16,17,20,24-26)$. Leaf blight disease of opium poppy caused by Helminthosporium species was rep-

Corresponding author: N. R. O’Neill; E-mail address: noneill@asrr.arsusda.gov

Publication no. P-2000-0421-01R

This article is in the public domain and not copyrightable. It may be freely reprinted with customary crediting of the source. The American Phytopathological Society, 2000. orted to be one of the most destructive diseases in Bulgaria, Switzerland, Czechoslovakia, the Netherlands, Romania, and Yugoslavia (23). The disease is known by several names: capsule rot, capsule blight, poppy fire, leaf blight disease, Helminthosporiosis, and spotted poppy Helminthosporium disease. Symptoms and signs have been found on all plant parts and at all stages of plant development (seedlings, crowns, roots, stems, leaves, pods, and capsules), although a few studies report that capsules are either more susceptible or are the only susceptible tissues $(2,23)$. One study reports that the pathogen is strictly a saprophyte of dying tissues of Papaver somniferum (14).

Helminthosporium disease on poppies was described in 1917 by Sawada (21) and was subsequently investigated by Girzitska (10), Christoff (4), and Barbacka (2). In these reports, D. penicillatum was considered the conidial form of $P$. calvescens (Fr. ex Desmaz.) Tul. (= $P$. papaveracea). Barbacka (2) noted that two fungi, $H$. papaveri and $D$. penicillatum, have been associated with the disease, but considers that references to the latter in the literature really refer to the former. Girzitska (10) reported a connection of $D$. penicillatum with $P$. papaveracea ( $=P$. calvescens) and, thus, considered them the same fungus. Christoff (4) reported $P$. calvescens to be the perfect stage of $H$. papaveri.

A review of the literature on the poppy disease pathogen describes strains, races, and a wide range of conidial dimensions, as well as the presence or absence of microsclerotia, chlamydospores, stromata, perithecia, and a Dendryphion-type of conidiophore (7). Reports suggested that production of different fungal structures varied, depending on cultural substrate and plant parts on which 
the fungus was growing, including seed $(1,15,16,22)$. Among the 26 isolates studied, Meffert (15) distinguished seven races or strains based on conidial morphology. In that report, a form of $D$. penicillatum was isolated that produced numerous, small, black sclerotia on seeds and young infected seedlings and a dark brown, penicillium-like, branching conidiophore different from $H$. papaveris conidiophores. Anamorphic strains of $H$. papaveris (teleomorph $P$. papaveracea) and $D$. penicillatum were recognized, and the sclerotia-producing strain was named $D$. penicillatum var. sclerotiale. Naumann (18) investigated the inhibition of different morphological strains of $H$. papaveris by actinomycete strains. Schmiedeknecht (22) evaluated 170 single-spore isolates from different locations in Germany and found differences in conidial size, aerial mycelia, spore production, and pigmentation. Czyzewska and Zarzycka (6) concluded that $H$. papaveris is probably not a uniform species, but composed of a few races differing chiefly in cultural appearance and spore size. Nevertheless, the causal agent of the poppy blight disease has been considered to be one morphologically variable species with an anamorphic and teleomorphic state $(7,24)$. Recent morphological and molecular genetic studies of isolates used in the current study show that $D$. penicillatum is a distinct fungus and not a part of the life cycle of $P$. papaveracea (8).

Although there are numerous reports describing the occurrence of poppy blight and resulting yield and seed losses (23), few investigations include information regarding the virulence or pathogenicity of isolates from artificial inoculations $(11,17,20)$. Research papers on the poppy blight disease generally report the use of one strain and do not adequately describe reproductive morphology or give a clear description of the morphological characteristics of their isolate. A distinction is not generally made between the disease caused by (or the cultures and inoculum derived from) different strains of the pathogen and there is no indication that conidial inoculum was derived from the anamorphic versus the teleomorphic state. Thus, the relative virulence or pathogenicity of strains or isolates reported in the literature is difficult to assess, and disease etiology is uncertain.

A further difficulty in determining the etiology of the poppy disease from previous reports is that the pathogen(s) are referred to by different names that may not be synonymous. The teleomorph synonym includes Pyrenophora pellita (Fr.) Rab., P. calvescens (Fr. ex Desmaz.) Tul., and P. papaveracea (de Not.) Sacc. The anamorph has been referred to as D. penicillatum (Corda) Fr., Dendryphium penicillatum (Corda) Fr., Brachycladium penicillatum Corda, D. papaveris (Sawada) Sawada, D. penicillatum var. sclerotiale, $H$. papaveris K. Sawada, and $H$. papaveri K. Sawada (7, $15,25,27)$.

Paramount to plant pathology investigations and the development of a biocontrol agent is the need to accurately determine the etiology of a disease. Demonstration that the organism isolated causes the observed symptoms is usually achieved by completing Koch's postulates. The objective of this study was to determine the etiology of poppy blight occurring in PI accessions grown in the greenhouse, growth chambers, and field and to conduct growth chamber studies to evaluate the potential for using the pathogens as bioherbicides for Papaver somniferum. Preliminary reports have been published $(12,19)$.

\section{MATERIALS AND METHODS}

Single-spore isolates were obtained by isolating single conidia from diseased poppy foliage and pods of plants growing in the field and growth chambers in Beltsville, MD. Isolates also were obtained from seed of five PI accessions, from dried infected capsules from Venezuela and Colombia, and from dried stem stubble of Papaver bracteatum and Papaver somniferum. Fungi were obtained from seed by the blotter method. Approximately 300 seeds per PI accession were soaked in $0.5 \% \mathrm{NaOCl}$ for $5 \mathrm{~min}$ and rinsed with sterile distilled water. Seeds were incubated on sterile moist filter paper in petri dishes at $24^{\circ} \mathrm{C}$ and evaluated daily for the appearance of fungi. Fungi were cultured on potato dextrose agar (PDA) (Difco Laboratories, Detroit) or half-strength V8 juice agar (100 ml of V8 juice, $2.0 \mathrm{~g}$ of $\mathrm{CaCO}_{3}, 16 \mathrm{~g}$ of agar, and 1 liter of distilled water). In April and May 1998, dry stems were collected from field stubble of poppy plants inoculated the previous spring. Fungi from this and other dried samples were obtained by placing tissue in a moist chamber, incubating as described above, and examined daily for the presence of fungi. Morphological descriptions of $D$. penicillatum and $P$. papaveracea were made from foliage and stems of inoculated poppy plants exhibiting symptoms of the disease. To determine whether there was an anamorph/teleomorph connection between the fungi, morphological characteristics were examined in at least 50 single-ascospore cultures obtained from pseudothecia produced by each $P$. papaveracea isolate and in a similar number of conidia from each fungus and isolate listed in Table 1.

Plant materials and fungal inoculum. Plants for the pathogenicity studies were grown from seed for 8 weeks in Jiffy Mix Plus potting medium (Jiffy Co., Shippegan, Canada) in 10-cmdiameter pots in a growth chamber with a 28 and $22^{\circ} \mathrm{C} 12-\mathrm{h}$ day/night temperature. Relative humidity was $40 \%$ or less, with an 11-h photoperiod from fluorescent lights at $500 \mu \mathrm{E} \mathrm{s}^{-1} \mathrm{~m}^{2}$. Pots were watered as needed to prevent wilting. Seed lots of Papaver somniferum were obtained from a local grocery (designated Indian Grocery [IG]), from an accession from Venezuela used for the production of opium (VEN), from the ornamental variety White Cloud (WC), and from PI accessions.

TABLE 1. Host, origin, and morphological characteristics of fungi isolated from Papaver somniferum-and Papaver bracteatum-infected seed and diseased foliage

\begin{tabular}{|c|c|c|c|c|c|c|}
\hline \multirow[b]{2}{*}{ Species } & \multirow[b]{2}{*}{ Isolate designation ${ }^{\mathrm{y}}$} & \multicolumn{3}{|c|}{ Fungal structures produced in culture ${ }^{\mathrm{z}}$} & \multirow[b]{2}{*}{ Host } & \multirow[b]{2}{*}{ Origin } \\
\hline & & Microsclerotia & $\begin{array}{l}\text { Dendryphion-type } \\
\text { conidiophores }\end{array}$ & Pseudothecia & & \\
\hline Dendryphion penicillatum & Cf96 & + & + & - & Papaver somniferum & Beltsville, MD \\
\hline Dendryphion penicillatum & $835-I-F 2-1$ & + & + & - & Papaver bracteatum & Sunnyside, WA \\
\hline Dendryphion penicillatum & 381B & + & + & - & Papaver bracteatum & Iran, PI381488 \\
\hline Dendryphion penicillatum & 415560 & + & + & - & Papaver somniferum & Afghanistan, PI415560 \\
\hline Pleospora papaveracea & B96 & - & - & + & Papaver somniferum & India, PI415573 \\
\hline Pleospora papaveracea & Pf96 & - & - & + & Papaver somniferum & Beltsville, MD \\
\hline Pleospora papaveracea & $19 \mathrm{C}$ & - & - & + & Papaver somniferum & Colombia \\
\hline Pleospora papaveracea & $251083-1$ & - & - & + & Papaver somniferum & Afghanistan, PI251083 \\
\hline Pleospora papaveracea & 414296 & - & - & + & Papaver somniferum & Sweden, PI414296 \\
\hline Pleospora papaveracea & VEN & - & - & + & Papaver somniferum & Venezuela \\
\hline
\end{tabular}

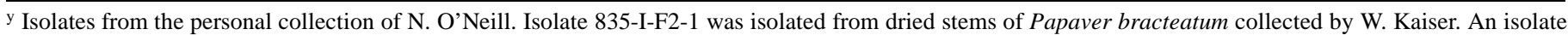
from the same material was deposited by W. Kaiser at the American Type Culture Collection (ATCC 46989) and at the Commonwealth Mycological Institute (CMI 246547).

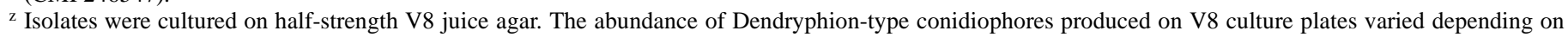
the isolate. 
Fungal inoculum was prepared by scraping conidia from 7- to 10-day-old V8 juice agar plates incubated at $23^{\circ} \mathrm{C}$ for 7 days with a 16-h photoperiod equipped with fluorescent lights. Conidia were suspended in sterile distilled water containing $0.001 \%$ Tween 20 at concentrations indicated for each experiment and then filtered through two layers of cheesecloth. Plants were sprayed at a rate of approximately $2.5 \mathrm{ml}$ per pot (to runoff). Pots were placed in a mist chamber at 22 to $24^{\circ} \mathrm{C}$ for $24 \mathrm{~h}$, or for times indicated, and returned to a growth chamber. Conditions for disease development in the growth chamber were 55 to $60 \%$ relative humidity with a 16 -h photoperiod under fluorescent lights at $24^{\circ} \mathrm{C}$. Disease assessments were based on a visual estimate of percent foliage blight on a 0 to 9 scale, in which $0=0$ to $3 \%, 1=3$ to $6 \%, 2=6$ to $12 \%, 3=$ 12 to $25 \%, 4=25$ to $50 \%, 5=50$ to $75 \%, 6=75$ to $87 \%, 7=87$ to $93 \%, 8=93$ to $96 \%$, and $9=96$ to $100 \%$ foliage necrosis

Pathogenicity of $\mathrm{D}$. penicillatum and $\boldsymbol{P}$. papaveracea to $\mathrm{Pa}$ paver somniferum cultivars. Poppy cvs. IG, WC, and VEN were inoculated with $D$. penicillatum isolate $\mathrm{Cf} 96$ or $P$. papaveracea isolate B96. Plants were inoculated with a spore suspension of $4 \times$ $10^{5}$ spores per $\mathrm{ml}$ and placed in a mist chamber for $24 \mathrm{~h}$. A fine mist was sprayed into the mist chamber for 1 min of every hour to maintain $100 \%$ humidity, and runoff of inoculum was not observed. The plants were returned to a growth chamber and evaluated daily for disease symptoms. The experiment consisted of four replicate pots randomized in the mist and growth chambers in complete blocks by isolate and cultivar, and the experiment was conducted twice. Control pots were inoculated with sterile distilled water containing $0.001 \%$ Tween 20 . The data was analyzed as a two-factor linear model using Proc Mixed (release 6.11; SAS Institute Inc., Cary, NC). Mean comparisons were done using pairwise contrasts (Table 2).

A similar experiment was conducted to determine the susceptibility of seedlings to poppy blight. Eighteen-day-old seedlings of Papaver somniferum cvs. WC and IG were inoculated with $P$. papaveracea isolate B96 and D. penicillatum isolate Cf96 at conidial concentrations of $4 \times 10^{5}$ spores per ml. Plants were given a 24-h wetness period, and disease was evaluated daily. The experiment consisted of four replicate pots of five seedlings per pot for each treatment and was conducted twice.

Virulence of $\boldsymbol{P}$. papaveracea and $\boldsymbol{D}$. penicillatum. The virulence of conidial inoculum from three isolates of $P$. papaveracea from different sources (Pf96, B96, and 19C) (Table 1) and conidia from D. penicillatum (Cf96) was determined on Papaver somniferum cvs. IG and WC. Inoculum concentration of the isolates was $3 \times 10^{5}$ spores per $\mathrm{ml}$, and plants were given a 24 -h wetness period. Disease was evaluated 5, 8, and 10 days after inoculation. The experiment included four replications of each treatment, and the experiment was conducted twice. The severity data was analyzed using Proc Mixed (release 6.11; SAS Institute Inc.). Mean

TABLE 2. Foliage blight severity in 8-week-old Papaver somniferum cvs. Indian Grocery, White Cloud, and an opium poppy accession from Venezuela (VEN) 7 days after inoculation with a conidial suspension of Dendryphion penicillatum isolate Cf96 and Pleospora penicillatum isolate B96

\begin{tabular}{lcc}
\hline & \multicolumn{2}{c}{ Disease severity $^{\mathrm{x}}$} \\
\cline { 2 - 3 } Cultivar & D. penicillatum & P. papaveracea \\
\hline Indian Grocery & $2.75 \mathrm{~b}^{\mathrm{y} * \mathrm{z}}$ & $9.00 \mathrm{a}$ \\
VEN & $4.25 \mathrm{~b}^{*}$ & $8.75 \mathrm{a}$ \\
White Cloud & $7.50 \mathrm{a}$ & $9.00 \mathrm{a}$
\end{tabular}

x Plants were rated for disease severity based on a visual estimate of percent foliage blight on a 0 to 9 scale, in which $0=0$ to $3 \%, 1=3$ to $6 \%, 2=6$ to $12 \%, 3=12$ to $25 \%, 4=25$ to $50 \%, 5=50$ to $75 \%, 6=75$ to $87 \%, 7=87$ to $93 \%, 8=93$ to $96 \%$, and $9=96$ to $100 \%$ foliage necrosis.

${ }^{y}$ Cultivars within a fungus with different letters are different at the $P<0.01$ significance level.

${ }^{\mathrm{z}}$ Asterisk indicates fungi within a cultivar are different at the $P<0.001$ significance level. comparisons for variables were done using pairwise contrasts and are given in Tables 3 and 4.

Effect of conidial inoculum concentration and wetness period on severity of foliage blight. The effects of inoculum concentration and wetness period on disease severity were each evaluated on Papaver somniferum cultivars inoculated with $D$. penicillatum isolate Cf96 and P. papaveracea isolate B96. In inoculum concentration experiments, conidial inoculum was prepared and applied to 8 -week-old plants at conidia spore densities of $1.5 \times 10^{5}, 7.5 \times 10^{5}$, $3.75 \times 10^{6}$, and $1.875 \times 10^{7}$ conidia per ml. Plants were placed in a mist chamber for $24 \mathrm{~h}$, returned to the growth chamber, and evaluated for foliage blight symptoms $3,5,7$, and 9 days after inoculation. The influence of wetness period on disease severity was investigated by inoculating Papaver somniferum cultivars with $3 \times$ $10^{5}$ conidia per $\mathrm{ml}$ and placing plants in a mist chamber for 0,6 , 12,24 , or $48 \mathrm{~h}$. Pots were returned to the growth chamber, and foliage blight assessments were made at $6,8,10,12$, and 14 days after inoculation. The experiments were designed as complete randomized blocks with four replications, and each experiment was conducted twice.

Analysis of variance was performed using the MIXED procedure in DAD (release 6.11; SAS Institute Inc.). Graphical examination of the residuals indicated heterogeneous variance, so the residual variance was partitioned into groups of similar variance. This procedure was used as an alternative to transforming the data (Table 5).

Disease development with conidial inoculum formulated with oil. The effect of oil inoculum formulation on severity of foliage blight in plants exposed to a short wetness period was determined using conidial inoculum formulated as a water or as a water and oil suspension. The length of dew period necessary for effective disease development in the field may be reduced by oil inoculum formulations (3). Ten-week-old WC and IG plants were inoculated with $P$. papaveracea isolate B96 and D. penicillatum isolate Cf96 conidia suspended in either sterile distilled water with Tween 20 or in sterile distilled water with $0,5,10$, and $30 \%$ unrefined corn oil (Spectrum Naturals, Inc., Petaluma, CA), at a concentration of $6 \times 10^{5}$ conidia per ml. Plants were placed in the mist chamber for $6 \mathrm{~h}$ and returned to a growth chamber. Disease assessments were conducted as described above at 3, 5, 7, and 10 days after inoculation. The experiment included four replicate pots for each treatment, and the experiment was conducted twice. The severity data was analyzed using Proc Mixed (release 6.11; SAS Institute Inc.). Mean comparisons for variables were done using pairwise contrasts.

\section{RESULTS}

In addition to many saprophytic genera and species of fungi, two pathogenic fungi were consistently isolated from diseased Papaver somniferum and Papaver bracteatum tissues and cultured on PDA and V8 juice agar (Table 1). Isolates of $D$. penicillatum and $P$. papaveracea, which have been shown to be different species, were obtained from infested seed, foliage, harvested infested pods, seedlings, and field stubble. Both fungi were found on symptomatic plants in the field in Maryland. Both species were isolated from seed from Venezuela, but only P. papaveracea was found on seed

TABLE 3. Mean comparisons of the virulence of Pleospora papaveracea isolates 19C, B96, and Pf96, and Dendryphion penicillatum isolate Cf96 to Papaver somniferum cvs. Indian Grocery and White Cloud

\begin{tabular}{lccll}
\hline & \multicolumn{4}{c}{ Isolate } \\
\cline { 2 - 5 } Cultivar & $19 \mathrm{C}$ & B96 & Cf96 & Pf96 \\
\hline Indian Grocery & $7.7 \mathrm{a}^{\mathrm{y}}$ & $7.2 \mathrm{a}^{* \mathrm{z}}$ & $2.38 \mathrm{~b}^{*}$ & $7.7 \mathrm{a}$ \\
White Cloud & $7.9 \mathrm{a}$ & $8.6 \mathrm{a}$ & $5.1 \mathrm{~b}$ & $8.2 \mathrm{a}$ \\
\hline
\end{tabular}

y Fungi within a cultivar with different letters are different at the $P<0.05$ significance level.

z Asterisk indicates that cultivars within a fungus are different at the $P<0.05$ significance level. 
from Colombia. Isolates of $D$. penicillatum but not $P$. papaveracea were obtained from Papaver bracteatum. Fungal structures of both species (conidia, pseudothecia, ascospores, microsclerotia, chlamydospores, and Dendryphion-type macronematous conidiophores with conidia) were observed and isolated from stem stubble pieces left from field plots that had been inoculated with either fungus the previous fall. Both species were often found on the same stubble pieces.

Single conidia isolated from Dendryphion-type conidiophores from infested seed, Papaver somniferum field stubble, or isolates in culture consistently produced $D$. penicillatum cultures. On V8 juice agar, $D$. penicillatum produced abundant conidia and numerous microsclerotia submerged in the medium. $P$. papaveracea produced abundant conidia and terminal and intercallary chlamydospores, but did not produce microsclerotia. $P$. papaveracea produced pseudothecia in cultures older than 30 days, but these rarely matured to produce ascospores. Pseudothecia with mature asci and ascospores were frequently produced embedded in filter paper from infested seed in moist chambers. Numerous microsclerotia of $D$. penicillatum were often produced on filter paper surrounding each infected seed.

The two species differed in morphological characteristics and were both pathogenic to opium poppy, although they differed in virulence. Described from diseased, inoculated plants, the fungi produced similar appearing, semimacronematous to micronematous conidiophores and conidia on inoculated leaves of Papaver somnif-

TABLE 4. Mean comparisons of the virulence of Pleospora papaveracea isolates 19C, B96, and Pf96, and Dendryphion penicillatum isolate Cf96 under different incubation periods

\begin{tabular}{lcccc}
\hline \multirow{2}{*}{$\begin{array}{l}\text { Incubation } \\
\text { period (days) }\end{array}$} & \multicolumn{4}{c}{ Isolate } \\
\cline { 2 - 5 } & $19 \mathrm{C}$ & B96 & Cf96 & Pf96 \\
\hline 5 & $6.1 \mathrm{~b}^{\mathrm{y}} a^{\mathrm{z}}$ & $6.6 \mathrm{~b} a$ & $3.3 \mathrm{~b} b$ & $6.8 \mathrm{~b} a$ \\
8 & $8.5 \mathrm{a} a$ & $8.3 \mathrm{a} a$ & $4.0 \mathrm{a} b$ & $8.3 \mathrm{a} a$ \\
10 & $9.0 \mathrm{a} a$ & $8.7 \mathrm{a} a$ & $3.8 \mathrm{ab} b$ & $8.7 \mathrm{a} a$ \\
\hline
\end{tabular}

y Days within an isolate with different letters are different at the $P<0.05$ significance level.

${ }^{\mathrm{z}}$ Fungi within an incubation period with different italicized letters are different at the $P<0.05$ significance level. Data are presented graphically in Figure 1.

TABLE 5. Analysis of variance of the influence of inoculum concentration and wetness period on severity of foliar blighting by Pleospora papaveracea isolate Pf96 and Dendryphion penicillatum isolate Cf96 to opium poppy (Papaver somniferum) cvs. White Cloud and Indian Grocery ${ }^{\mathrm{z}}$

\begin{tabular}{lcrl}
\hline Source & $\begin{array}{c}\text { Degrees of } \\
\text { freedom }\end{array}$ & Type III $F$ & $P$ \\
\hline Inoculum concentration, experiment & 1 & 171.4 & 0.0001 \\
$\quad$ Cultivar & 1 & 403.62 & 0.0001 \\
Isolate & 1 & 0.45 & 0.5014 \\
Cultivar $\times$ isolate & 3 & $2,319.48$ & 0.0001 \\
Inoculum concentration & 3 & 9.97 & 0.0001 \\
Cultivar $\times$ inoculum concentration & 3 & 42.58 & 0.0001 \\
Isolate $\times$ inoculum concentration & 3 & 29.99 & 0.0001 \\
Cultivar $\times$ isolate $\times$ inoculum concentration & 3 & 319.63 & 0.0001 \\
Incubation period & 3 & 8.75 & 0.0001 \\
Cultivar $\times$ incubation period & 3 & 18.76 & 0.0001 \\
Isolate $\times$ incubation period & 3 & 0.38 & 0.7651 \\
Cultivar $\times$ isolate $\times$ incubation period & & & \\
Wetness period, experiment 1 & 1 & 301.97 & 0.0001 \\
Cultivar & 1 & 615.20 & 0.0001 \\
Isolate & 1 & 2.67 & 0.1034 \\
Cultivar $\times$ isolate & 4 & $3,925.64$ & 0.0001 \\
Wetness period & 4 & 53.84 & 0.0001 \\
Cultivar $\times$ wetness period & 4 & 140.81 & 0.0001 \\
Isolate $\times$ wetness period & 11.39 & 0.0001 \\
Cultivar $\times$ isolate $\times$ wetness period & 4 & 415.82 & 0.0001 \\
Incubation period & 4 & 62.61 & 0.0001 \\
Wetness period $\times$ incubation period & 16 & &
\end{tabular}

${ }^{\mathrm{z}}$ Data are presented graphically in Figures 2 and 3. erum. However, other morphological characters distinguished the fungi from each other. Conidiophores produced by $D$. penicillatum were 40 to $95 \mu \mathrm{m}$ long, 4 to $5 \mu \mathrm{m}$ thick, and yellow brown, with one to three branches along the conidiophore. Conidia were solitary or catenulate, $23.3 \mu \mathrm{m}$ (standard deviation $[\mathrm{SD}]=4.3$ ) long, and $5.3 \mu \mathrm{m}(\mathrm{SD}=0.64)$ wide, cylindrical, rounded at the ends or obclavate, pale to olive to light brown, and minutely granulate, with 2.95 ( $\mathrm{SD}=0.54$ ) septa. Dendryphion-type conidiophores were occasionally produced in culture on V8 juice and PDA agar, as well as on seed surfaces and dead overwintered poppy stem debris from the field. These conidiophores were long, straight, septate, dark brown, tapering, and branched toward the apex to produce conidia at the tip (7). They arose singly or in fascicles of two to four from microsclerotia produced on substrate surfaces.

Conidiophores produced by the anamorph of $P$. papaveracea were 45 to $100 \mu \mathrm{m}$ long, 4 to $5 \mu \mathrm{m}$ thick, and pale yellow brown, with one to two branches along the conidiophore. Conidia were solitary or catenulate, $45.6 \mu \mathrm{m}(\mathrm{SD}=12.6)$ long, $7.2 \mu \mathrm{m}(\mathrm{SD}=0.68)$ wide, cylindrical, rounded at the ends or obclavate, pale olive to light brown, and minutely granulate, with $5.08(\mathrm{SD}=1.85)$ septa and transverse walls becoming darker than the outer wall. Ascomata were 200 to $400 \mu \mathrm{m}$, black, globose, and smooth. Ascospores were brown and 18 to $23 \times 7$ to $9 \mu \mathrm{m}$, with three septa and the middle cells containing a single vertical septum. $P$. papaveracea produced chlamydospores infrequently in culture, and microsclerotia or Dendryphion-type conidiophores were not observed. Conidial dimensions of both fungi grown in culture media were considerably smaller and more variable than conidia from diseased material (data not shown).

Single conidia from isolates of either species and single ascospores from pseudothecia of $P$. papaveracea (Table 1) consistently produced cultures exhibiting characteristics of the parent isolate. All single-ascospore cultures and conidia from the P. papaveracea anamorph exhibited cultural characteristics of this species. Conidia from $D$. penicillatum and from Dendryphion-type conidiophores produced cultures characteristic of $D$. penicillatum. Thus, no anamorph/teleomorph connection was established. $P$. papaveracea was homothallic, producing pseudothecia in all singleascospore cultures.

Pathogenicity of $\mathrm{D}$. penicillatum and $\boldsymbol{P}$. papaveracea to $\mathrm{Pa}$ paver somniferum cultivars. Both $D$. penicillatum (Cf96) and $P$. papaveracea (B96) were pathogenic and highly virulent to Papaver somniferum cvs. IG, WC, and an accession from Venezuela (VEN) used for the production of opium (Table 2). Symptoms began as

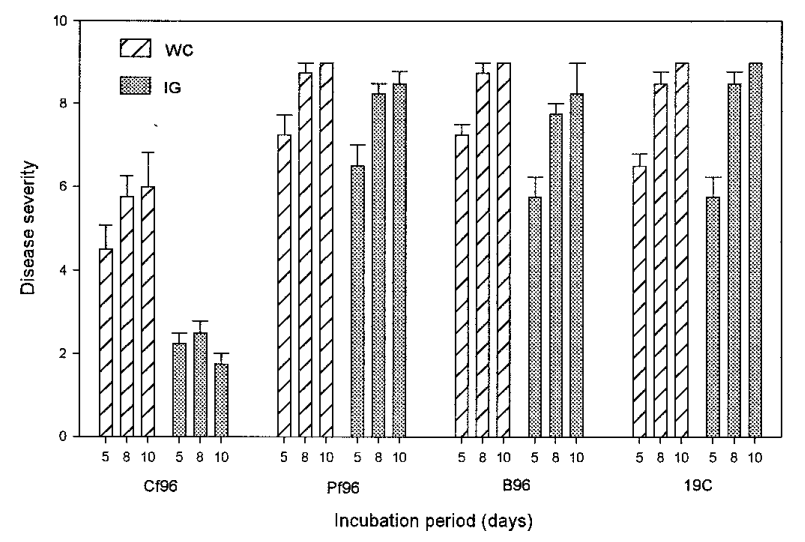

Fig. 1. Virulence of Pleospora papaveracea isolates Pf96, B96, 19C, and Dendryphion penicillatum isolate Cf96 to Papaver somniferum cvs. Indian Grocery (IG) and White Cloud (WC). Plants were rated for disease severity based on a visual estimate of percent foliage blight on a 0 to 9 scale, in which $0=0$ to $3 \%, 1=3$ to $6 \%, 2=6$ to $12 \%, 3=12$ to $25 \%, 4=25$ to $50 \%$, $5=50$ to $75 \%, 6=75$ to $87 \%, 7=87$ to $93 \%, 8=93$ to $96 \%$, and $9=96$ to $100 \%$ foliage necrosis. 
chlorotic spots and leaf margin chlorosis, progressed to watersoaked areas on stems and foliage, and finally to necrosis of all tissues. Necrotic areas became covered with a dense layer of conidiophores and conidia beginning $48 \mathrm{~h}$ after inoculation. No symptoms occurred in control plants. Ratings taken 7 days after inoculation revealed that $P$. papaveracea was more virulent to IG and VEN than was $D$. penicillatum and that there were significant differences in susceptibility among cultivars to D. penicillatum. Cultures derived from conidia reisolated from diseased tissues consistently produced cultures of the respective fungus from which the inoculum was derived.

Seedlings were highly susceptible to both pathogens. Eighteenday-old WC and IG seedlings exhibited necrotic spots $48 \mathrm{~h}$ after inoculation. By 5 days, $P$. papaveracea-inoculated seedlings were killed, and seedlings inoculated with $D$. penicillatum were 87 to $93 \%$ necrotic. There was no significant difference in susceptibility between cultivars (data not shown).
Virulence of $P$. papaveracea and $\boldsymbol{D}$. penicillatum. Isolates of P. papaveracea from different sources (Pf96, B96, and 19C) were equally virulent, causing over $90 \%$ foliage blight in WC and IG 8 days after inoculation (Fig. 1; Tables 3 and 4). P. papaveracea isolates were more virulent to Papaver somniferum cultivars than were $D$. penicillatum isolates throughout the 10 -day incubation period. IG was less susceptible to $D$. penicillatum than was WC.

Effect of conidial inoculum concentration and wetness period on severity of foliage blight. Varying inoculum concentrations and wetness periods resulted in significant differences in foliage blight disease severity in Papaver somniferum cvs. IG and WC inoculated with $D$. penicillatum isolate Cf96 and $P$. penicillatum isolate B96 (Figs. 2 and 3; Table 5). Low inoculum concentrations and the use of cultivars differing in susceptibility revealed that $P$. papaveracea is more virulent to opium poppy than is $D$. penicillatum and that WC is more susceptible than IG. However, all plants were dead 9 days after inoculation with inoculum con-
A
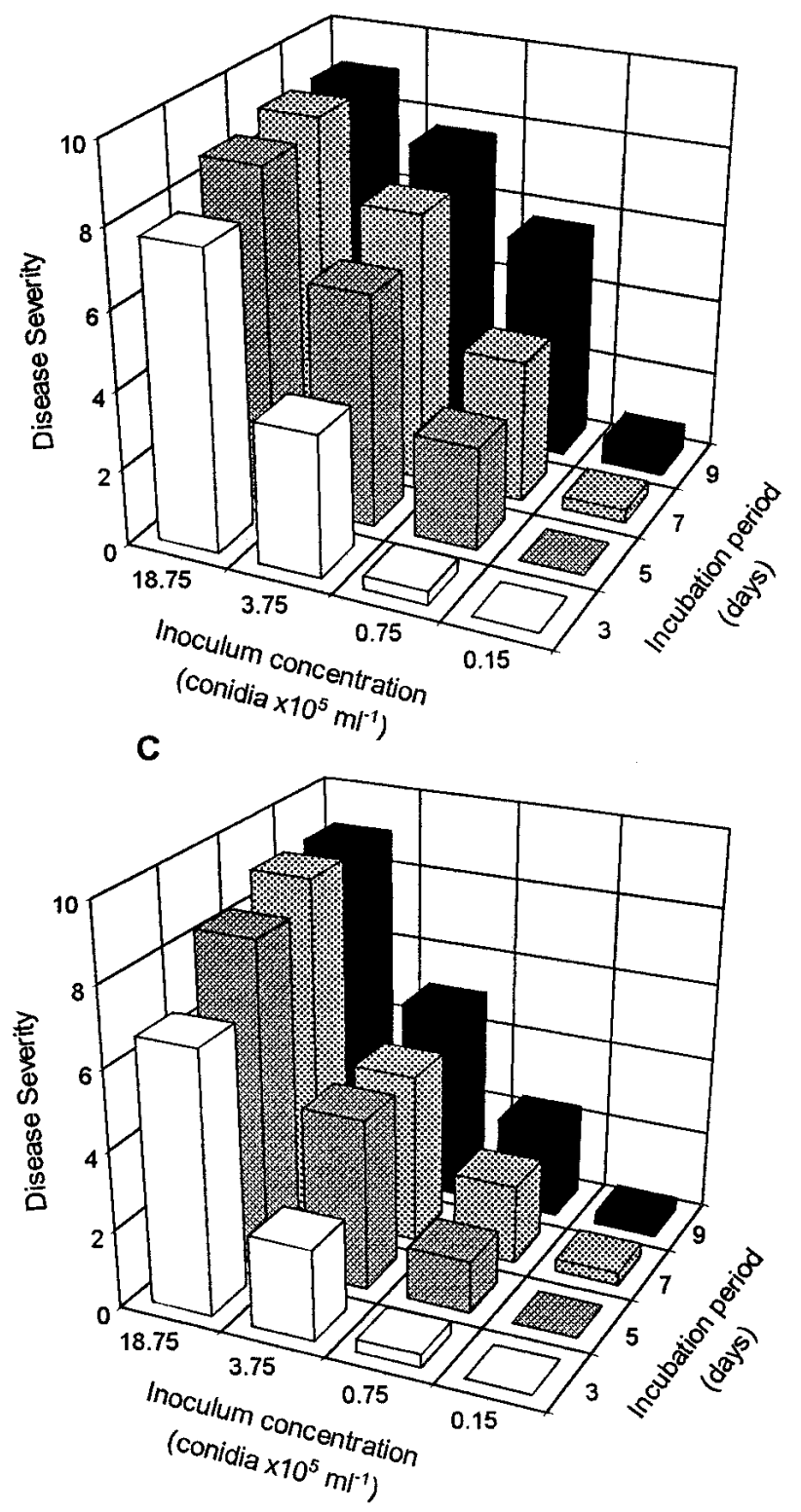

B
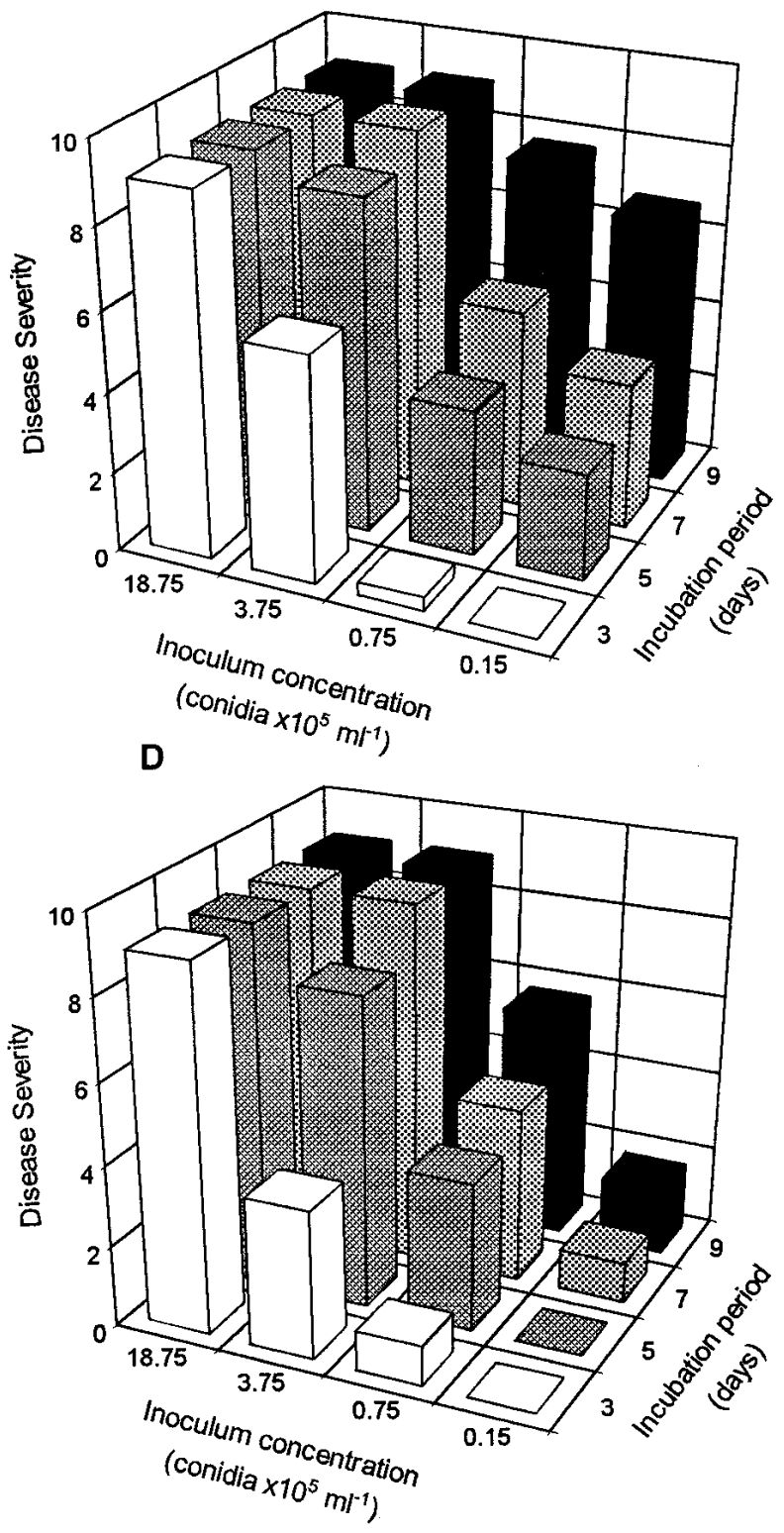

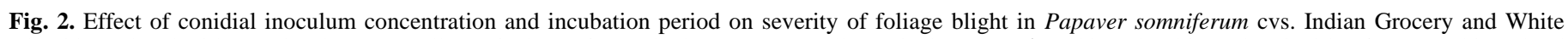

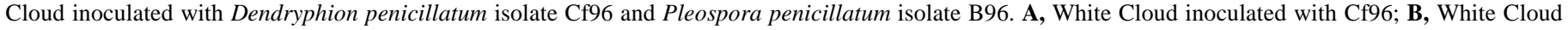

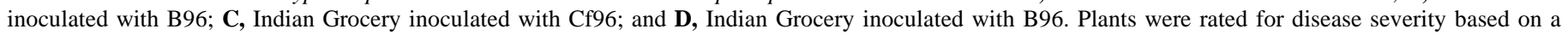

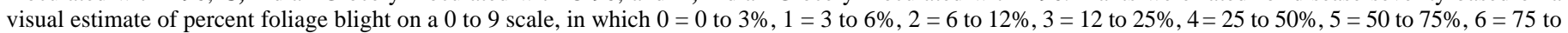
$87 \%, 7=87$ to $93 \%, 8=93$ to $96 \%$, and $9=96$ to $100 \%$ foliage necrosis. 
centrations of $1.8 \times 10^{6}$ spores per ml of either pathogen (Fig. 2) or with longer wetness periods (Fig. 3). A wetness period of at least $6 \mathrm{~h}$ was necessary to achieve 25 to $50 \%$ foliage necrosis (disease rating of 4) 12 days after inoculation with B96. Similar results were obtained when the experiments were repeated.

Disease development with conidial inoculum formulated with oil. Oil inoculum formulation enhanced disease severity in $\mathrm{Pa}$ paver somniferum caused by $P$. papaveracea and $D$. penicillatum (Fig. 4; Table 6). Plants of WC and IG inoculated with conidia of either pathogen in $30 \%$ oil and given a 6-h wetness period exhibited 25 to $50 \%$ foliage necrosis 3 days after inoculation. Under these conditions, $D$. penicillatum was almost as virulent as $P$. papaveracea, and WC and IG were equally susceptible. Disease severity using oil formulations of 5 and $10 \%$ were proportionally less effective than $30 \%$ oil (data not shown). Oil formulation facilitated an even distribution of inoculum over leaf surfaces, resulting in more uniform necrosis.

\section{DISCUSSION}

We report that two different fungi cause poppy blight and that they are distinguishable by several morphological criteria. $D$. penicillatum produced conidia, abundant microsclerotia, and less frequently, Dendryphion-type macronematous conidiophores on infested seed in infected foliage, culture, and Papaver somniferum field stubble. $P$. papaveracea consistently produced pseudothecia, chlamydospores, and conidia that were larger than conidia of $D$. penicillatum. Except for the absence of Dendryphion-type conidiophores, the conidia and conidiophores of the anamorph of $P$. papaveracea resembled those of $D$. penicillatum. However, we found that the conidia of $D$. penicillatum were comparatively smaller, especially when taken from diseased tissues. Their similar appearance, along with the fact that both fungi are pathogenic to poppy and appear to occupy the same ecological niche, may have led to reports that the poppy fungus was a single species with races or variable spore
A

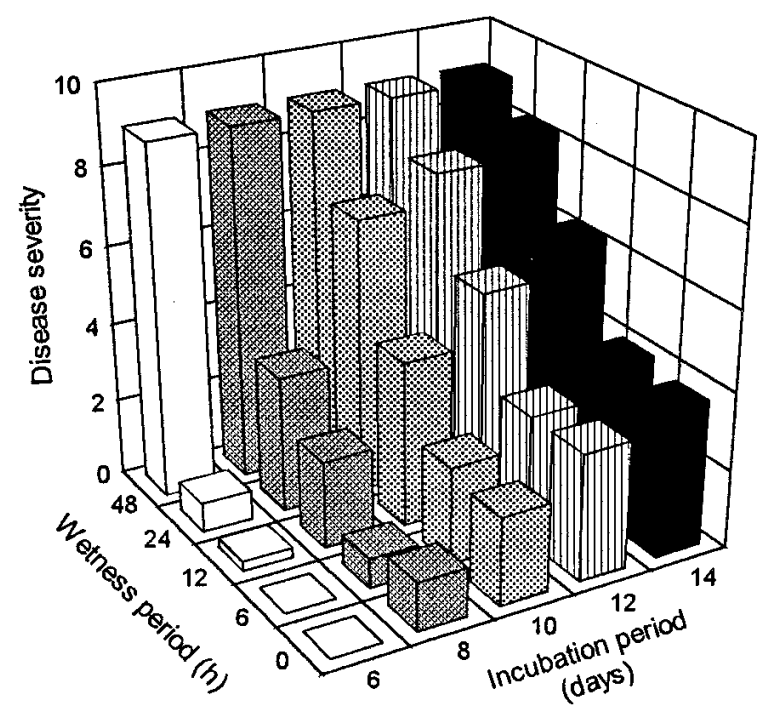

C

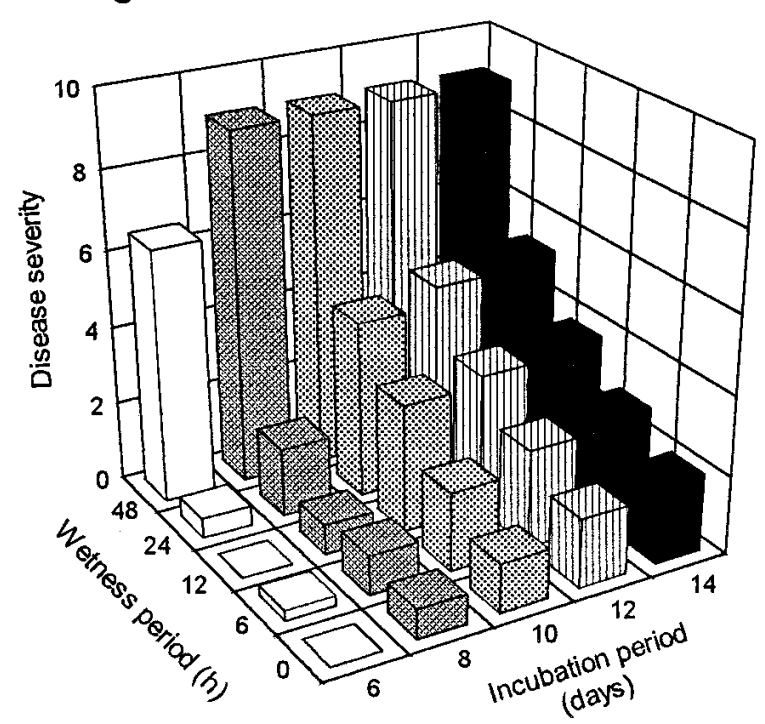

B

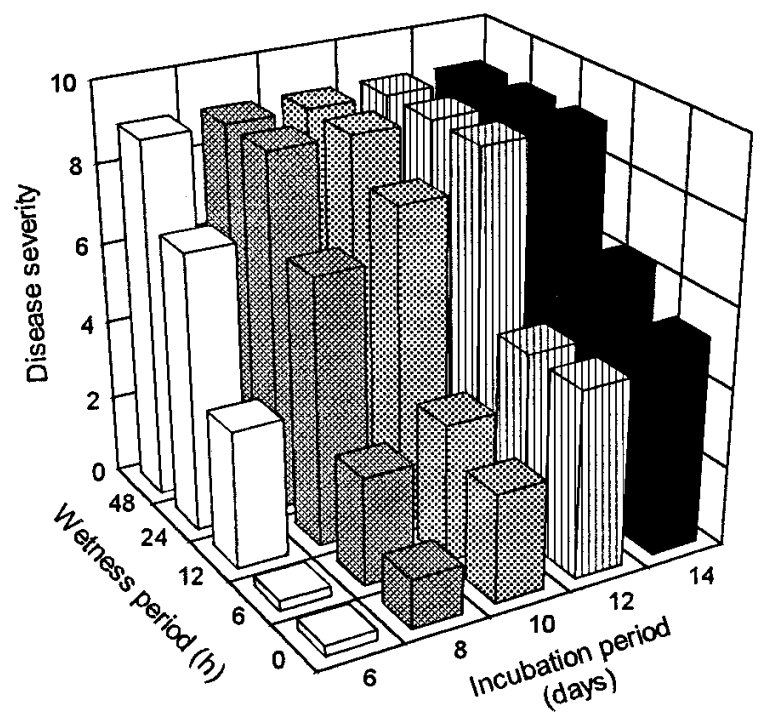

D

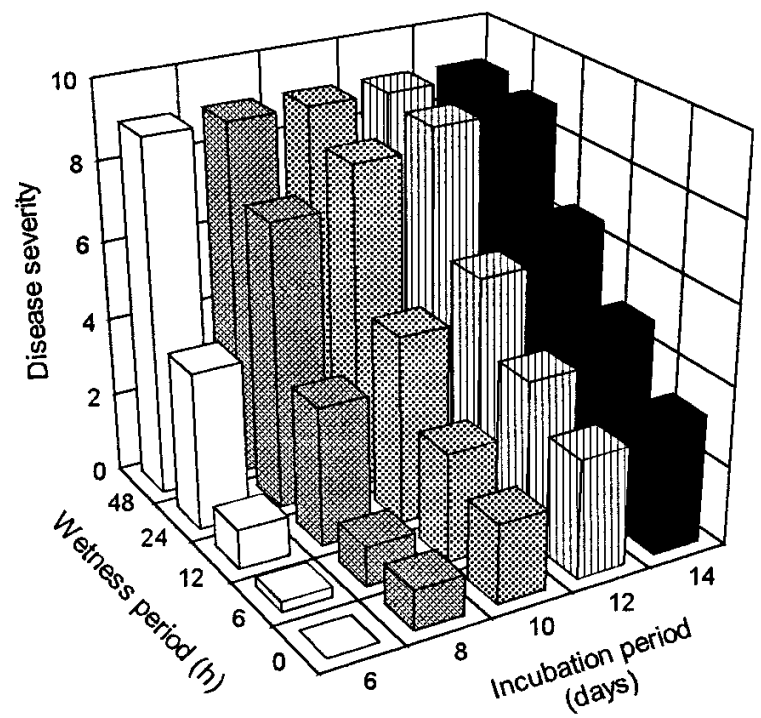

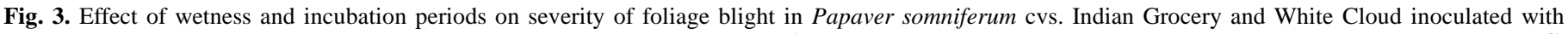

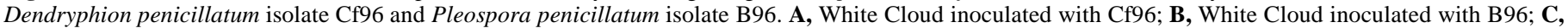

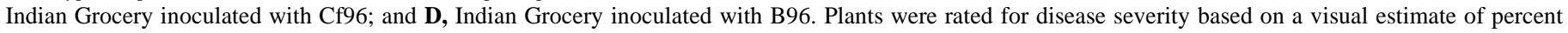

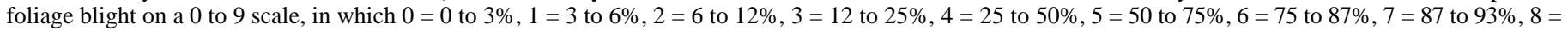
93 to $96 \%$, and $9=96$ to $100 \%$ foliage necrosis. 
sizes. We also found, as did Christoff (4) and Milatović (16), that measurements of conidia taken from culture differed from those taken from diseased tissues.

Completion of Koch's postulates (Fig. 1; Table 2) revealed that $D$. penicillatum and $P$. papaveracea are both pathogenic to opium poppy. However, P. papaveracea may have more potential for use as a mycoherbicide, because it is more virulent and produces ascospores in addition to conidia. Field tests are needed to determine the effectiveness of ascospores in disease development in the spring. It also is possible that microsclerotia produced by $D$. penicillatum will give this pathogen an advantage if they are shown to function as overwintering propagules. Both fungi produce abundant mycelia in liquid and solid media, but sporulation is more limited in liquid media (data not shown). Investigations on optimizing formulations are needed to determine the economic feasibility of producing large quantities of inoculum.

The influence of different factors on disease development in controlled conditions was investigated, including incubation period, wetness period, inoculum concentration, and seedling and mature plant susceptibility. Oil inoculum formulations resulted in enhanced disease under a reduced (6-h) wetness period. Results from this experiment suggest that less-susceptible cultivars may become severely diseased, even when using the less-virulent species $(D$. penicillatum) when inoculum is oil-formulated to enhance disease.

Both pathogens appear to have a good potential for development as mycoherbicides. Seedlings as well as mature plants are susceptible and, depending on environmental conditions, rapidly become completely blighted. Dense layers of new spores devel-

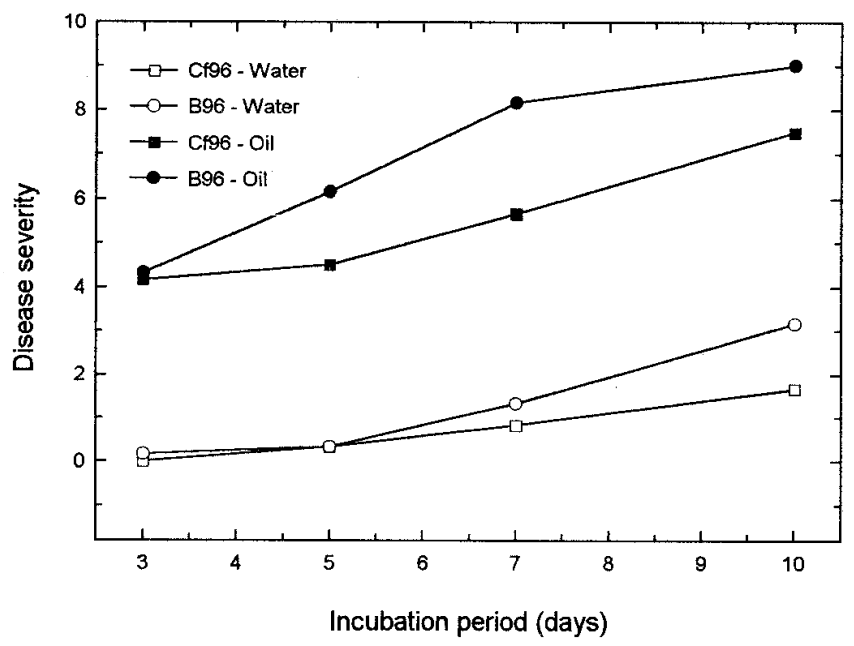

Fig. 4. Influence of oil conidial inoculum formulation with Pleospora papaveracea isolate B96 and Dendryphion penicillatum isolate Cf96 on disease severity in Papaver somniferum cvs. White Cloud and Indian Grocery. Plants were rated for disease severity based on a visual estimate of percent foliage blight on a 0 to 9 scale, in which $0=0$ to $3 \%, 1=3$ to $6 \%, 2=6$ to $12 \%, 3=$ 12 to $25 \%, 4=25$ to $50 \%, 5=50$ to $75 \%, 6=75$ to $87 \%, 7=87$ to $93 \%, 8=$ 93 to $96 \%$, and $9=96$ to $100 \%$ foliage necrosis.

TABLE 6. Mean comparisons of the effect of oil formulation on the severity of disease caused by Pleospora papaveracea isolate B96 and Dendryphion penicillatum isolate Cf96

\begin{tabular}{lccccl}
\hline \multirow{2}{*}{$\begin{array}{l}\text { Incubation } \\
\text { period (days) }\end{array}$} & \multicolumn{2}{c}{ Oil $^{\mathrm{y}}$} & & \multicolumn{2}{c}{ Water } \\
\cline { 2 - 3 } \cline { 5 - 6 } & B96 & CF96 & & B96 & CF96 \\
\hline 3 & $4.3 \mathrm{c}^{\mathrm{z}}$ & $4.2 \mathrm{c}$ & & $0.2 \mathrm{c}$ & $0.0 \mathrm{c}$ \\
5 & $6.2 \mathrm{~b}^{*}$ & $4.5 \mathrm{c}$ & & $0.3 \mathrm{c}$ & $0.3 \mathrm{bc}$ \\
7 & $8.2 \mathrm{a}^{*}$ & $5.7 \mathrm{~b}$ & & $1.3 \mathrm{~b}$ & $0.8 \mathrm{~b}$ \\
10 & $9.0 \mathrm{a}^{*}$ & $7.5 \mathrm{a}$ & & $3.2 \mathrm{a}^{*}$ & $1.7 \mathrm{a}$ \\
\hline
\end{tabular}

y Oil and water treatment means are different at the $P<0.001$ significance level.

${ }^{\mathrm{z}}$ Incubation period within a treatment and isolate with different letters are different at the $P<0.01$ significance level. Asterisk indicates that isolates differ within an incubation period and formulation at the $P<0.05$ significance level. Data are presented graphically in Figure 4. oped on necrotic plant surfaces, an important aspect for continued spread development of an epidemic in the field. The occurrence of both fungi on field stubble in 1998 and 1999 suggests that the fungi can successfully overwinter, at least under the climatic conditions that occurred in Maryland.

Field studies are needed to evaluate the respective potentials of each pathogen as candidates for biological control. We currently are investigating pathogen formulations for field application, host range, yield and alkaloid level losses due to disease, molecular and genetic analyses of the fungi, and disease susceptibility in Papaver somniferum collections.

\section{ACKNOWLEDGMENTS}

We thank J. Saunders for bringing poppy blight to our attention. We also thank W. Kaiser for supplying disease specimens for our studies; M. Giannetti, D. Clark, and M. Blum for excellent technical assistance and helpful suggestions; and D. Liewehr for conducting the statistical analyses.

\section{LITERATURE CITED}

1. Ballarin, C. 1950. Unterscuhungen über Helminthosporium papaveris. Phytopathol. Z. 16:399-442.

2. Barbacka, K. 1935. Helminthosporium na maku uprawnym (Helminthosporium papaveri K. Sawada). [Helminthosporiosis of cultivated poppy.] Mem. No. 242. Inst. Nat. Polonais Econ. Rurale Pulawy 16:73-88.

3. Boyette, C. D. 1994. Unrefined corn oil improves the mycoherbicidal activity of Colletotrichum truncatum for hemp sesbania (Sesbania exaltata) control. Weed Technol. 8:526-529.

4. Christoff, A. 1930. Some plant diseases new to Bulgaria. Sci. Zemledelieta 11:3-6.

5. Crosier, W. F., and Heit, C. E. 1964. Seed-borne fungi of anchusa, China aster, poppy and zinnia. Assoc. Off. Seed Anal. Proc. 54:87-92.

6. Czyzewska, S., and Zarzycka, H. 1960 Niektore dian z biologii grzyba Helminthosporium papaveris Hennings, stadium doskonale Pleospora papaveracea (Wint.) de Not. [Some data on the biology of the fungus Helminthosporium papaveris Henn., imperfect stage of Pleospora papaveracea (Wint.) de Not.] Acta Agrobot. 10:41-51.

7. Ellis, M. B. 1971. Pages 504-505 in: Dematiaceous Hyphomycetes. Commonw. Mycol. Inst., Kew, Surrey, England.

8. Farr, D. F., O'Neill, N. R., and van Berkum, P. B. 1999. Morphological and molecular studies on Dendryphion penicillatum and Pleospora papaveracea, pathogens of Papaver somniferum. Mycologia 92:145-153.

9. Flachs, K. 1936. Krankheiten und Schädlinge an Ölpflanzen. [Diseases and pests of oil-poppy.] Nachr. Schädlingsbekampung 11:130-148.

10. Girzitska, Z. K. 1930. Conidien von Pleospora papaveracea Sacc. [Conidial stage of Pleospora papaveracea Sacc.]. Rev. Appl. Mycol. 9:488.

11. Grummer, G. 1951. Beiträge zur Eigenschaftanalyse der Anfälligkeit von Papaver somniferum gegen Helminthosporium papaveris1. [Contributions toward the specific analysis of susceptibility of Papaver somniferum to Helminthosporium papaveris I.] Mitt. Zuchter 21:306322.

12. Hebbar, K. P., O'Neill, N. R., Bailey, B. A., and Lumsden, R. D. 1997. Fermentation and formulation of Dendryphion penicillatum, a potential mycoherbicide of Papaver somniferum. (Abstr.) Phytopathology 87(suppl.):S41.

13. Kaiser, W. J. 1983. Plant introduction and related seed pathology research in the United States. Seed Sci. Technol. 11:1197-1212.

14. Mass Geesteranus, H. P. 1960. Pyrenophora calvescens on seed poppies (Papaver somniferum). Tijdschr. Plantenziekten 4:237-248.

15. Meffert, M. E. 1950. Ein beitrag zur biologie und morphologie der erreger der parasitären blattdurre des mohns. Z. Parasitenkunde 14:442-498.

16. Milatović, I. 1952. Study of the fungus Pleospora calvescens (Fr.) Tulasne on poppy. Poljopr. Znan. Smotra 13:3-12.

17. Mraz, F. 1960. Vliv škodliveho pusobeni houby Helminthosporium papaveris Hennig na vynosy Maku v Karlovy Vary letech 1957 a 1958. [Influence of the harmful effect of the fungus $H$. papaveris on poppy yields in the region of Karlovy vary in the years 1957 and 1958.] Cesk. Akad. Zemed. Sborn 33:1083-1094.

18. Naumann, K. 1958. Über das Verhalten verschiedener morphologischer Rassen von Helminthosporium papaveris Saw gegenüber unterschiedlisch aktiven Strahlenpilzstämmen. [On the reaction of different morphological strains of $H$. papaveris to actinomycete strains of differing activity.] Arch. Mikrobiol. 28:417-442.

19. O’Neill, N. R., and Jennings, J. C. 1997. Dendryphion penicillatum, a destructive seed-borne pathogen of Papaver somniferum. (Abstr.) Phyto- 
pathology 87(suppl.):S73.

20. Radulescu, E., and Perseca, E., 1964. Über die biologie des pilzes Pleospora papaveracea (De Not.) Sacc. Rev. Roum. Biol. Ser. Bot. 9:19-33.

21. Sawada, X. 1917. Helminthosporium papaveris Sawada. Trans. Formosan Nat. Hist. Soc. 32:129.

22. Schmiedeknecht, M. 1958. Morphologische Untersuchungen zur Frage der Rrassenbildung bei Helminthosporium papaveris Saw. Arch. Mikrobiol. 28:404-416.

23. Schmitt, C. G., and Lipscomb, B. 1975. Pathogens of selected members of the Papaveraceae-An annotated bibliography. Agric. Res. Serv., U.S.
Dep. Agric., Beltsville, MD.

24. Sehgal, S. P., Gupta, I. J., and Agrawat, J. M. 1971. Capsule rot of opium poppy (Papaver somniferum L.). Rajasthan J. Agric. Sci. 2:61-62.

25. Sivanesan, A., and Holliday, P. 1982. Pleospora papaveracea. CMI Descriptions of Pathogenic Fungi and Bacteria No. 730. Commonw. Mycol. Inst., Kew, Surrey, England.

26. Tanaka, T. 1920. New Japanese fungi. Notes Translations-IX 12:329333.

27. Wehmeyer, L. E. 1949. Studies in the genus Pleospora. I. Mycologia 41: 565-593 